\title{
PEPTIDA ANTIMIKROBIAL
}

\author{
Hendra Gunawan, R.M Rendy Ariezal Effendi \\ Departemen Ilmu Kesehatan Kulit dan Kelamin \\ FK Universitas Padjadjaran/RSUP Dr. Hasan Sadikin Bandung
}

\begin{abstract}
ABSTRAK
Peptida antimikrobial (PAM) merupakan kelompok peptida di permukaan sel epitel yang bersifat mikrobisidal dan sitolitik. Peptida ini berperan dalam respons imun bawaan, sebagai lini pertama dalam pertahanan terhadap infeksi dengan cara membunuh langsung bakteri, jamur, atau virus. Dua kelompok besar PAM yang terdapat pada manusia yaitu defensin dan katelisidin. Defensin diklasifikasikan menjadi tiga tipe yaitu alfa, beta, dan teta defensin. Pada manusia, hanya terdapat satu tipe katelisidin yaitu human cathelicidin antimicrobial protein 18 (hCAP18), dengan LL-37 sebagai bentuk aktifnya. Tipe PAM lainnya pada manusia yaitu psoriasin, RNase 7, dan dermsidin. Mekanisme kerja PAM yaitu berikatan dengan membran sel mikroba dan membentuk sebuah celah, sehingga terjadi perubahan permeabilitas membran yang mengakibatkan sel mengalami lisis. Jumlah PAM akan meningkat saat terjadi infeksi dan inflamasi. Perubahan pola ekspresi PAM terdapat pada beberapa penyakit kulit yang mengalami inflamasi kronik misalnya psoriasis, dermatitis atopik, rosasea, akne vulgaris, hidradenitis supuratif, infeksi virus, dan lupus eritematosus sistemik. Hingga sat ini terus dikembangkan penelitian terhadap peranan PAM dalam bidang dermatologi. Beberapa jenis PAM yang saat ini tersedia di pasaran antara lain Plectasin ${ }^{\circledR}$, Magainins ${ }^{\circledR}$, Pexiganan ${ }^{\circledR}$.
\end{abstract}

Kata kunci: defensin, katelidisin, peptida antimikrobial

\section{ANTIMICROBIAL PEPTIDES}

\section{ABSTRACT}

Antimicrobial peptide (AMP) is a group of peptide that can be found in epithelial cells surface, which has microbicidal and cytolytic properties. This AMP participates in the innate immune response by providing the first line defense against infection by directly eliminating bacteria, fungi, or virus. Two large groups of AMP in human are defensin and cathelicidin. The defensins are categorized in three types: alpha, beta, and theta defensin. In human, the cathelicidin is limited to a single type, referred as human cathelicidin antimicrobial protein 18 (hCAP18), with its active form named as LL-37. Other types of AMP in human are psoriasin, RNase 7 , and dermcidin. The mechanism of action of AMP is thought to relate to their ability to bind membranes of microbes and form a pore in the membrane, therefore changes in membrane permeability may lead to cell lysis. $A M P$ will increase in number in response to infection and inflammation. Altered expression of AMP has been recognized in some chronic inflammatory skin diseases such as psoriasis, atopic dermatitis, rosacea, acne vulgaris, hidradenitis suppurativa, viral infection, and systemic lupus erythematosus. Until now, the studies of the role of AMP in dermatology continue to be developed. AMP that is currently commercially available includes Plectasin ${ }^{\circledR}$, Magainins ${ }^{\circledR}$, Pexiganan ${ }^{\circledR}$.

Key words: antimicrobial peptide, cathelicidin, defensin

Korespondensi:

Jl. Pasteur 38 Bandung 40161

Telp/Fax 022-2032426

Email: endaguna@yahoo.com 


\section{PENDAHULUAN}

Resistensi antibiotik merupakan masalah yang sangat penting saat ini. Untuk mengatasi hal tersebut dibutuhkan golongan antibiotik baru. Peptida antimikrobial (PAM) merupakan kandidat yang ideal. Peptida antimikrobial (PAM) adalah kelompok peptida yang terdapat di permukaan sel epitel (misalnya epidermis), yang bersifat mikrobisidal dan sitolitik. ${ }^{1}$ Peptida ini berperan dalam respons imun bawaan, ${ }^{2}$ sebagai lini pertama dalam pertahanan terhadap infeksi ${ }^{2,3}$ dengan cara membunuh langsung

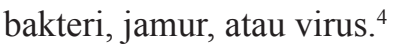

Meskipun keberadaan PAM telah diketahui sejak lebih dari 20 tahun yang lalu, tetapi fungsinya dalam respons imun baru diketahui belakangan ini. Sejumlah PAM telah diidentifikasi berdasarkan kemampuannya dalam menghambat pertumbuhan mikroba patogen. ${ }^{2}$ Dua kelompok besar PAM5 yang terdapat pada manusia yaitu defensin dan katelisidin.,6 Beberapa hasil penelitian membuktikan bahwa defensin dan katelisidin berperan sebagai antibiotik alamiah dan sebagai signalling molecules yang dapat mengaktivasi sel inang agar berperan dalam pertahanan tubuh. ${ }^{2}$ Mekanisme kerja PAM yaitu dengan cara berikatan dengan membran sel mikroba dan membentuk sebuah pore (celah), ${ }^{7,8}$ sehingga terjadi perubahan permeabilitas membran, yang pada akhirnya menyebabkan sel mengalami lisis. ${ }^{7}$

Perubahan pola ekspresi PAM berhubungan pula dengan kondisi patologis beberapa penyakit inflamasi pada kulit misalnya psoriasis, dermatitis atopik, rosasea, ${ }^{4,7}$ atau akne vulgaris. ${ }^{4}$ Berbagai penelitian saat ini dilakukan untuk mengetahui peranan PAM dalam berbagai penyakit infeksi dan inflamasi, serta menjadikan PAM sebagai salah satu alternatif terapi dalam mengobati penyakitpenyakit tersebut. ${ }^{4}$
Dalam makalah ini akan dibahas mengenai struktur PAM, mekanisme kerjanya terhadap invasi mikroba, dan keterlibatannya dalam beberapa penyakit inflamasi pada kulit.

\section{STRUKTUR PEPTIDA ANTIMIKROBIAL}

Peptida antimikrobial dihasilkan oleh beberapa sel di kulit yaitu keratinosit, kelenjar keringat, neutrofil, dan sel mast. Peptida antimikrobial (PAM) yang diekspresikan pada beberapa sel ini berperan sebagai sawar pada permukaan kulit. ${ }^{3}$ Dua kelas PAM utama yang ditemukan pada kulit adalah defensin dan katelisidin. , $^{7,10}$

\section{Defensin}

Defensin merupakan peptida yang terdiri atas 2844 asam amino dengan tiga ikatan disulfida. ${ }^{9}$ Defensin banyak terdapat pada sel dan jaringan yang terlibat dalam mekanisme pertahanan tubuh terhadap infeksi ${ }^{6}$ yaitu keratinosit, monosit, makrofag, ${ }^{1,9}$ neutrofil, sel Paneth, ${ }^{6}$ atau sel epitel mukosa dari sistem respirasi, pencernaan, dan reproduksi. ${ }^{1,9}$ Sel Paneth berperan dalam mekanisme pertahanan tubuh yang terdapat di usus halus dan dilepaskan setelah mendapat stimulus berupa pajanan bakteri. ${ }^{6}$

Defensin disintesis sebagai pro-peptida 93-96 asam amino, terdiri atas regio sinyal N-terminal anionic prosegment dan C-terminal cationic region (Gambar 1). Pelepasan C-terminal region dari regio sinyal pro-segment oleh enzim elastase, metaloproteinase, atau enzim proteolitik lainnya akan menimbulkan aktivitas antimikrobial (peptida matur). ${ }^{1,9,10}$ Defensin memiliki sifat spektrum antibiotik luas yang mampu membunuh bakteri, virus, atau jamur. ${ }^{2}$ Defensin diklasifikasikan menjadi 3 tipe yaitu alfa, beta, dan teta defensin., ${ }^{2,49}$

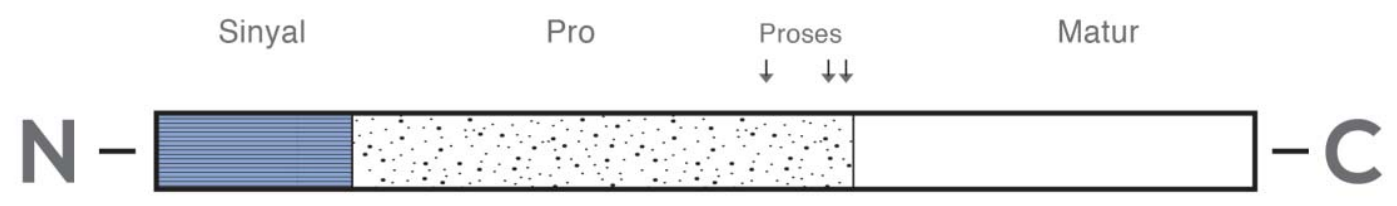

Gambar 1. Gambar skematik defensin

\section{Alfa-Defensin}

Alfa-defensin mempunyai 29-35 residu asam amino dengan pola ikatan disulfida 1-6, 2-4, dan 3-5.2 Alfadefensin dapat terdeposit sebagai pro-peptida (pada sel Paneth) atau sebagai peptida aktif yang matur (pada neutrofil). Neutrofil mengandung kadar defensin yang tinggi bila terdapat pada jaringan yang sedang mengalami inflamasi. ${ }^{6}$ Hingga saat ini terdapat enam alfa-defensin yang telah teridentifikasi. Empat alfa-defensin yang terdapat di dalam neutrofil disebut human neutrophil peptides
$(\mathrm{HNP})^{3}$ dan dua alfa-defensin lainnya yang banyak terdapat pada sel Paneth ${ }^{6}$ dan sel epitel saluran urogenital ${ }^{2,3}$ disebut human defensins 5 dan 6 (HD5 dan HD6). ${ }^{2,6}$

\section{Beta-Defensin}

Beta-defensin terdiri atas 36-42 rangkaian asam amino dengan ikatan disulfida 1-5, 2-4, 3-6 dan daerah N-terminal yang lebih panjang dibandingkan dengan alfa-defensin. ${ }^{2,9}$ Beta-defensin dapat menarik sel dendritik dan sel memori $\mathrm{T}$ sehingga berperan sebagai peng- 
hubung antara sistem imun bawaan dan didapat.,11 Pada manusia terdapat empat tipe beta-defensin yaitu human beta defensin (HBD)-1, HBD-2, HBD-3, dan HBD-4. ${ }^{2,3}$ Human beta defensin-1 (HBD-1) banyak terdapat pada ginjal, sedangkan HBD-2 diekspresikan dalam jumlah sedikit pada epitel kulit normal, tetapi diregulasi dalam jumlah banyak pada kulit yang mengalami inflamasi. ${ }^{2}$ Pada keratinosit, HBD-2 disekresikan di dalam badan lamelar. ${ }^{6}$ Sitokin pro-inflamasi berupa tumor necrosis factor- $\alpha$ (TNF- $\alpha$ ) dan interleukin-1 (IL-1) dapat menstimulasi keratinosit untuk menghasilkan HBD-2.7 Ekspresi HBD-2 distimulasi pula oleh mikroba misalnya Pseudomonas aeruginosa, Staphylococcus aureus, dan Candida albicans. HBD-3 dipurifikasi dari skuama pasien psoriasis, sedangkan HBD-4 banyak terdapat pada sel epitel sistem pernapasan. ${ }^{2}$

\section{Teta-Defensin}

Teta-defensin dibentuk dari ligasi dua rangkaian 9 residu asam amino yang berasal dari prekursor alfadefensin. Teta-defensin merupakan peptida matur yang menjadi stabil oleh tiga ikatan disulfida. ${ }^{6}$ Tipe defensin ini terdapat pada primata, sedangkan pada manusia tidak teraktivasi akibat proses mutasi. ${ }^{4}$

\section{Katelisidin}

Katelisidin merupakan PAM kedua terbesar yang diproduksi oleh mamalia. ${ }^{1}$ Katelisidin disintesis sebagai pro-peptida dan diproses menjadi peptida yang aktif oleh beberapa enzim proteolitik. Manusia dan tikus hanya mempunyai satu gen katelisidin, sedangkan mamalia lain misalnya babi mempunyai beberapa variasi gen katelisidin. Katelisidin merupakan PAM pertama pada mamalia yang mempunyai aktivitas antimikrobial spektrum luas dan poten. ${ }^{2}$ Katelisidin pada manusia hanya mempunyai satu tipe yaitu human cathelicidin antimicrobial protein 18 (hCAP18). Human cathelicidin antimicrobial protein 18 (hCAP18) diproses oleh proteinase 3 di neutrofil untuk melepaskan bentuk aktifnya yaitu LL-37 (Gambar 2). 2,7 LL-37 merupakan dua residu leusin dan 37 asam amino panjang. LL-37 berperan dalam respons imun bawaan, baik melalui aktivitas antimikrobial secara langsung maupun melalui penarikan sel-sel pertahanan tubuh. $^{2}$

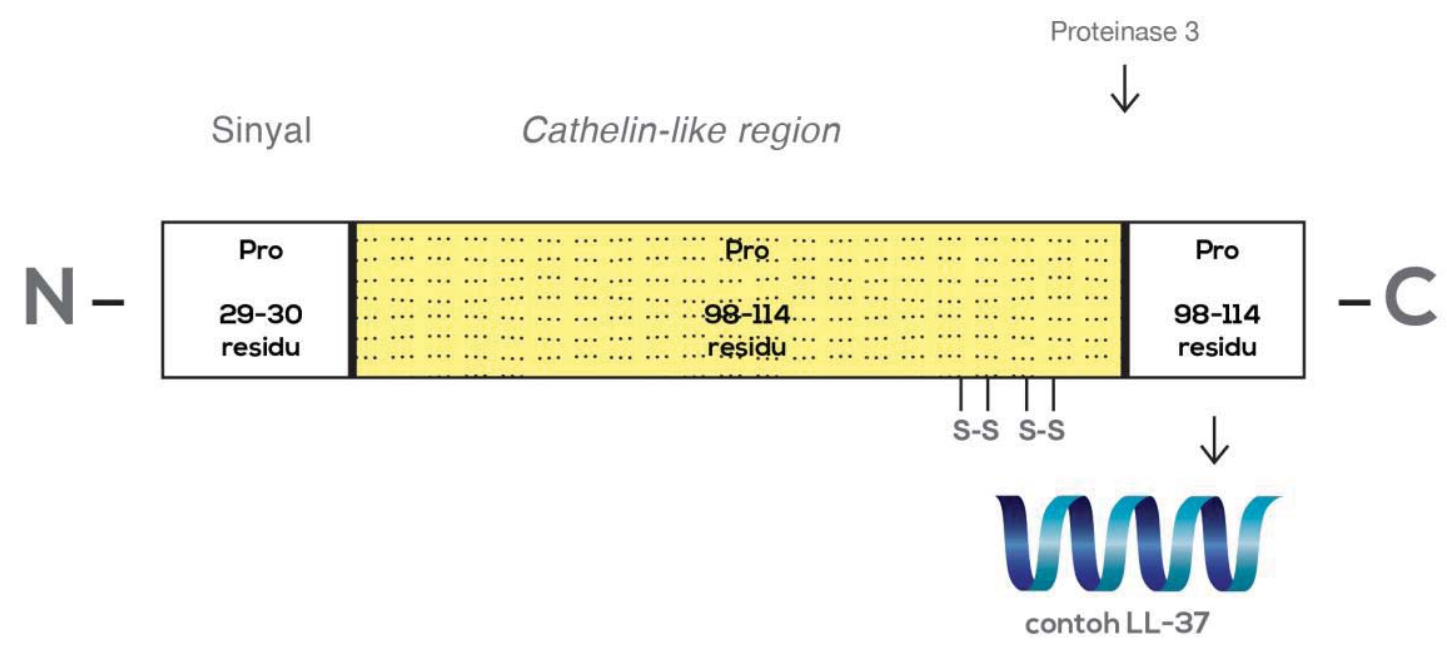

Gambar 2. Gambar skematik katelisidin pada manusia

\section{Jenis PAM Lain}

Psoriasin, RNase 7, dan dermsidin merupakan jenis PAM lain yang terdapat pada manusia. Pada kulit, psoriasin dan RNase 7 dihasilkan oleh keratinosit, sedangkan dermsidin disekresikan oleh kelenjar keringat. ${ }^{7}$ Psoriasin mempunyai efek antimikroba dengan cara mengganggu permeabilitas membran bakteri. Peptida antimikrobial (PAM) tipe ini terdapat pula pada epitel saluran cerna dan berperan dalam mengeliminasi bakteri di usus misalnya Escherechia coli (E. coli). ${ }^{4,71}$ RNase 7 diisolasi dari stratum korneum pada kulit manusia sehat. RNase 7 mempunyai aktivitas ribonuklease poten dan aktivitas antimikrobial terhadap S.aureus, E.coli, C.albicans, (P.acnes), dan P.aeruginosa. ${ }^{4,7}$ Dermsidin mempunyai aktivitas antimikrobial luas terhadap S. aureus, E. coli, C.albicans, dan Enterococcus faecium (E. faecium). ${ }^{7}$

\section{MEKANISME KERJA PAM TERHADAP INVASI MIKROBA}

Mekanisme kerja PAM yaitu dengan cara mengganggu metabolisme dan menghancurkan membran mikroba. ${ }^{12}$ Jumlah PAM akan meningkat saat terjadi infeksi, inflamasi, atau diferensiasi epidermis. ${ }^{4}$ Interaksi antara PAM dengan mikroba bersifat elektrostatik, yaitu terjadi interaksi antara PAM yang bersifat kationik dengan komponen bakteri, jamur, atau virus yang bersifat anionik. ${ }^{3,12}$ 
Komposisi asam amino dan muatan kation memudahkan PAM untuk menempel dan masuk ke dalam sel melalui celah yang telah terbentuk pada membran. ${ }^{8,12}$ Dapat pula masuk ke dalam sel secara langsung untuk mengikat molekul intraselular yang penting bagi sel hidup. ${ }^{12}$

Bagian terluar lapisan membran (outer leaflet) bakteri, sebagian besar mengandung lipid bermuatan negatif. Sebaliknya, pada binatang dan tumbuh-tumbuhan, bagian terluar lapisan membran mengandung lipid (kolesterol) tanpa disertai muatan positif maupun negatif. Setelah berikatan dengan PAM, sebagian besar lipid bermuatan negatif akan memisahkan diri menuju lapisan membran bagian dalam yang berhadapan dengan sitoplasma. ${ }^{12}$

Mekanisme kerja PAM seperti yang tampak pada gambar 3 memperlihatkan bahwa (a) PAM akan menempel di bagian terluar membran mikroba. (b) Integrasi PAM pada membran menyebabkan permukaan luar membran menipis, selanjutnya terjadi peregangan pada lapisan bilayer. (c) Kemudian terbentuk celah yang bersifat sementara pada fase transisi. (d) Lipid dan PAM bergerak menuju bagian dalam membran. (e) Difusi PAM menuju target intraselular. (f) Membran sel target akan rusak membentuk fragmen-fragmen. ${ }^{12}$

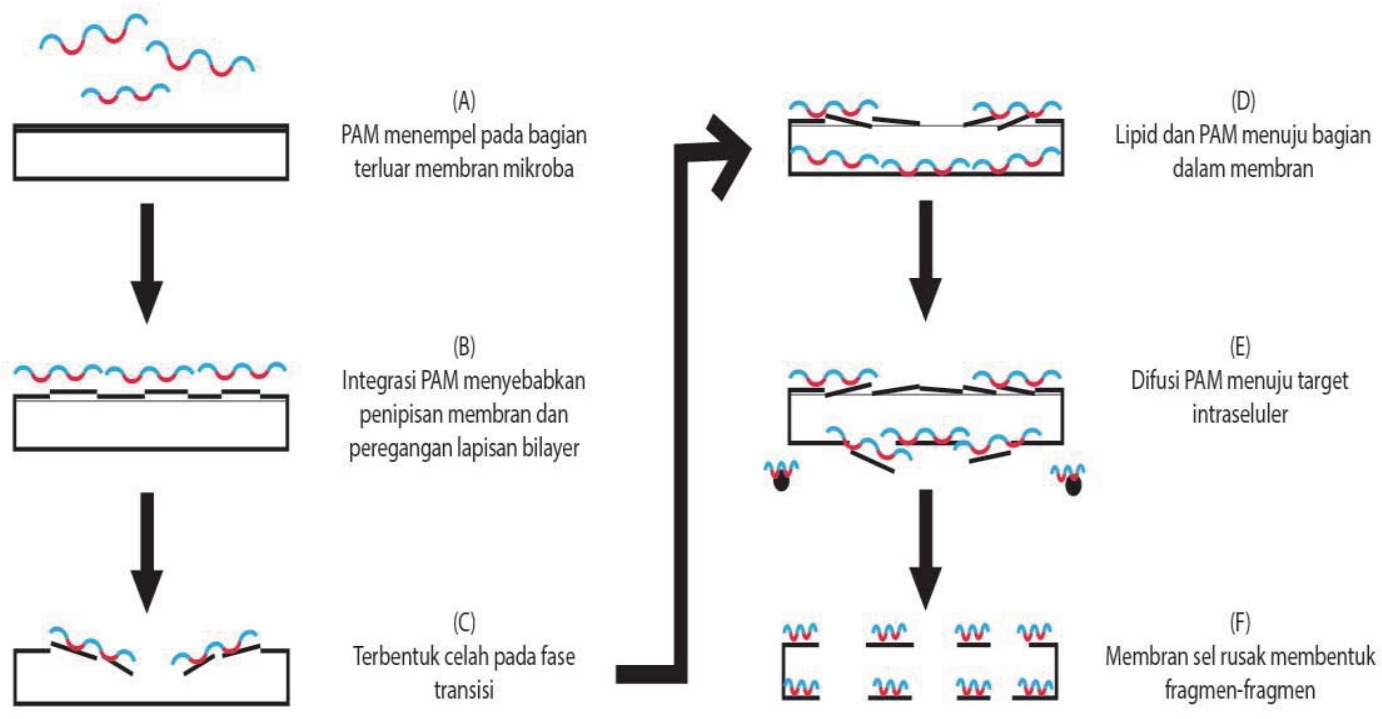

Gambar 3. Gambar skematik mekanisme kerja PAM

Mekanisme PAM dalam membunuh mikroba melibatkan struktur PAM itu sendiri. Kation PAM berinteraksi dengan komponen anion bakteri, virus, atau jamur sehingga menyebabkan penetrasi PAM.,6,8 Kandungan protein yang bersifat bakterisidal berupa amphipatic, alpha-helical peptides (cecropins dan magainins), dan peptida yang mengandung disulfida (defensin) mampu berikatan dengan target membran dan membentuk celah. ${ }^{8}$

Selain LL-37, jenis katelisidin lain adalah prolin/ arginine-rich cathelicidin (PR-39), yang telah terbukti berperan dalam membunuh mikroba. ${ }^{8}$ Peptida antimikrobial (PAM) ini merupakan peptida aktif yang melakukan penetrasi secara linear pada membran mikroba dan tidak membentuk celah dalam mekanisme kerjanya. Setelah berikatan dengan PR-39, mikroba akan mengalami penurunan sintesis protein, selanjutnya akan mengalami kematian sel. ${ }^{3}$ Hal ini merupakan jalur alternatif dari mekanisme kerja PAM. ${ }^{8}$
Pada mekanisme kerja klasik, PAM (misalnya defensin) berikatan dengan membran mikroba dan membentuk sebuah celah yang besar. Pada mekanisme kerja alternatif, PAM (misalnya PR-39) tidak membentuk celah pada membran, tetapi melakukan penetrasi linear melalui beberapa lapisan lipid dan berikatan dengan reseptor protein yang terdapat dalam sitoplasma. ${ }^{3,8}$

\section{KETERLIBATAN PAM DALAM PENYAKIT IN- FLAMASI PADA KULIT}

Peptida antimikrobial pada kulit pertama kali diidentifikasi saat PR-39 ditemukan dalam cairan luka porcine, setelah itu LL-37 ditemukan pada keratinosit. ${ }^{2}$ Pada beberapa penyakit kulit ditemukan perubahan pola ekspresi PAM. HBD-1 dan HBD-2 dapat ditemukan pada lesi akne vulgaris dan diduga berperan dalam patogenesis penyakit ini. HBD-2 dan HBD-3 tidak terdapat pada kulit normal, tetapi terdapat pada keratinosit lesi psoriasis. 
Hal ini menunjukkan peranan kedua PAM ini pada kulit yang mengalami inflamasi kronis. ${ }^{2}$ HBD-3 memiliki efek antimikroba kuat terhadap S. aureus dan E. faecium yang resisten terhadap vankomisin. HBD-3 adalah $\beta$-defensin pertama yang memiliki aktivitas terhadap bakteri gram positif. $^{7}$

Katelisidin diekspresikan pada kulit yang mengalami inflamasi. ${ }^{2}$ LL-37 diekspresikan pada lesi kulit pasien psoriasis, dermatitis kontak alergi karena nikel, lupus eritematosus sistemik (SLE), veruka vulgaris, dan kondiloma akuminatum. ${ }^{2,8}$ Pada penelitian dengan menggunakan hibridisasi in situ dan reverse transcriptase polymerase chain reaction (RT-PCR), ekspresi LL-37 tidak terdeteksi pada kulit yang tidak mengalami inflamasi. Hal ini menunjukkan bahwa katelisidin lebih berperan terutama pada respons inflamasi dibandingkan dengan memodulasi permukaan epitel utuh yang mengandung kolonisasi bakteri. $^{8}$

Dalam keadaan normal, PAM terdapat dalam jumlah sedikit di beberapa lokasi yaitu struktur folikular dan kelenjar keringat. ${ }^{2}$ Pada saat terjadi infeksi maupun inflamasi, keratinosit meningkatkan produksi PAM. ${ }^{4,8}$ Pada saat yang bersamaan, kandungan PAM meningkat pula di dalam sel mast dan neutrofil. PAM mempunyai aktivitas kemotaktik yang akan mengeliminasi mikroba dan berperan dalam proses penyembuhan luka. ${ }^{2}$ Perubahan pola ekspresi PAM berperan dalam menentukan kerentanan seseorang terhadap beberapa penyakit kulit antara lain psoriasis, dermatitis atopik, dan rosasea. ${ }^{4}$

\section{Psoriasis}

Peptida antimikrobial telah diketahui terlibat dalam patogenesis psoriasis. Ekspresi PAM dapat diinduksi oleh sitokin pro-inflamasi misalnya TNF- $\alpha$ yang berperan penting dalam patogenesis psoriasis. ${ }^{13,14}$ Harder dkk. ${ }^{15}$ pada tahun 2001 mempublikasikan hasil penelitiannya mengenai identifikasi HBD-3 pada skuama pasien psoriasis. Satu tahun kemudian, Ong dkk. ${ }^{16}$ menemukan peningkatan ekspresi katelisidin dan HBD-2 yang meningkat pada lesi kulit pasien psoriasis, baik tingkat messenger ribonucleic acid (mRNA) maupun tingkat protein. Pada tahun 2005, Harder dkk. ${ }^{17}$ menemukan ekspresi PAM lainnya pada skuama pasien psoriasis yaitu HNP-1, HNP-2, dan HNP-3.

Pada patogenesis psoriasis telah diketahui keterlibatan sitokin-sitokin yang dihasilkan oleh sel $T$ helper (Th) 17 yaitu IL-17 dan IL-22. ${ }^{18}$ Sitokin-sitokin ini berperan dalam mencetuskan reaksi inflamasi pada kulit pasien psoriasis. ${ }^{19}$ Ekspresi HBD-2 meningkat pada pasien psoriasis karena diregulasi oleh IL-17 dan IL-22. ${ }^{13}$

Katelisidin LL-37 diekspresikan dalam jumlah banyak pada lesi psoriasis. ${ }^{14}$ Pada penelitian yang dilakukan oleh Kim dkk. ${ }^{20}$ diketahui bahwa pengobatan psoriasis dengan kalsipotriol dapat menurunkan ekspresi HBD-2 dan LL-37. Hal ini menunjukkan bahwa kalsipotriol dapat menghambat ekspresi HBD-2 dan LL-37 yang distimulasi oleh TNF- $\alpha$.

Psoriasin terlibat dalam patogenesis psoriasis ${ }^{7,21}$ melalui disregulasi diferensiasi keratinosit dan proses inflamasi. Ekspresi psoriasin diregulasi oleh interferon dan berperan dalam menarik limfosit ke lokasi inflamasi. Melalui pemeriksaan real-time-PCR, ekspresi psoriasin meningkat pada lesi psoriasis tipe plak. ${ }^{21}$

\section{Dermatitis Atopik}

Berbeda dengan psoriasis, pada lesi kulit pasien dermatitis atopik didapatkan penurunan ekspresi HBD-2 dan HBD-3.,11,16 Hasil penelitian yang dilakukan Ong dkk. ${ }^{16}$ menunjukkan penurunan secara signifikan ekspresi HBD-2 dan LL-37 pada lesi kulit pasien dermatitis atopik. Sitokin Th2 yang berperan dalam patogenesis dermatitis atopik yaitu IL-4 dan IL-13 dapat menekan ekspresi mRNA HBD-2 dan HBD-3 yang diinduksi TNF- $\alpha$ pada keratinosit. ${ }^{7,16}$ Penurunan ekspresi PAM ini menunjukkan bahwa pasien dermatitis atopik rentan terhadap infeksi kulit, ${ }^{4}$ misalnya terhadap S. aureus atau virus herpes simpleks (VHS). ${ }^{7}$ Rieg dkk. ${ }^{22}$ dalam penelitiannya melaporkan penurunan jumlah dermsidin pada keringat pasien dermatitis atopik.

\section{Rosasea}

Pada lesi kulit pasien rosasea, didapatkan ekspresi katelisidin abnormal dalam jumlah besar. ${ }^{4,16}$ Hasil analisis spektrometri menunjukkan bahwa pada pasien rosasea, katelisidin diproses secara abnormal menjadi bentuk peptida yang tidak ditemukan pada kulit normal. ${ }^{4}$ Abnormalitas proses katelisidin ini disebabkan meningkatnya stratum corneum tryptic enzyme (SCTE)., ${ }^{4,7}$ Berdasarkan pengamatan tersebut diketahui bahwa abnormalitas PAM dapat menyebabkan terjadinya eksaserbasi penyakit inflamasi pada kulit. ${ }^{4}$

\section{Infeksi Virus}

Peningkatan ekspresi PAM terhadap infeksi virus pada kulit masih belum jelas, ${ }^{1,2}$ tetapi beberapa penelitian menunjukkan korelasi antara penurunan PAM dengan peningkatan kejadian infeksi virus pada kulit. ${ }^{2,4}$ Pada kulit pasien dermatitis atopik dengan eczema herpeticum menunjukkan penurunan ekspresi katelisidin, dan pada mencit yang mengalami defisiensi katelisidin memperlihatkan kadar herpes simplex virus tipe 2 (HSV-2) yang tinggi. Hal tersebut menjelaskan kerentanan pasien dermatitis atopik terhadap infeksi $\mathrm{HSV}^{4}$

\section{Penyakit Kulit Lain}

Kadar katelisidin yang tinggi dapat ditemukan pada 
penyakit lupus eritematosus sistemik. Ekspresi HNP-3 yang tinggi dapat ditemukan pada pasien limfoma sel T. ${ }^{4}$ Peningkatan ekspresi HBD-1 dan HBD-2 terdapat pada lesi pasien akne vulgaris yang dicetuskan oleh infeksi $\mathrm{P}$. acnes. ${ }^{4}$ Hasil penelitian yang dilakukan Hofmann $\mathrm{dkk} .{ }^{23}$ menunjukkan bahwa pada penyakit hidradenitis supurativa (akne inversa) didapatkan peningkatan ekspresi HBD-3 dan penurunan ekspresi RNase 7.

\section{POTENSI TERAPI}

Berdasarkan beberapa hasil penelitian terbukti bahwa PAM efektif terhadap organisme patogen yang resisten terhadap obat konvensional. ${ }^{24}$ Peptida antimikrobial (PAM) bersifat bakterisidal dan tidak membutuhkan waktu kontrol yang lama untuk membunuh bakteri. ${ }^{5,12}$ Sejumlah peptida dan turunannya telah dikembangkan sebagai terapi antiinfeksi baru untuk berbagai kondisi patologis. Plectasin $®$ merupakan turunan defensin yang diisolasi dari jamur saprofit Pseudoplectania nigrella. PAM ini efektif terhadap Streptococcus pneumonie. ${ }^{25}$ Magainins ${ }^{\circledR}$ yang diisolasi dari kulit hewan Xaenopus laevis,

\section{DAFTAR PUSTAKA}

1. Pasupuleti M. Structural, functional and evolutionary studies of antimicrobial peptides. Doctoral dissertation. Lund: Lund Faculty of Medicine; 2009. h. 8-14.

2. Bardan A, Nizet V, Gallo RL. Antimicrobial peptides and the skin. Expert Opin Biol Ther. 2004;4:543-9.

3. Izadpanah A, Gallo RL. Antimicrobial peptides. J Am Acad Dermatol. 2005;52:381-8.

4. Kenshi Y, Gallo RL. Antimicrobial peptides in human skin disease. Eur J Dermatol. 2008;18:11-21.

5. Schauber J, Gallo RL. Expanding the roles of antimicrobial peptides in skin: Alarming and arming keratinocytes. J Invest Dermatol. 2007;127:510-2.

6. Ganz T. Defensins: Antimicrobial peptides of innate immunity. Nat Rev Immunol. 2003;3:710-20.

7. Modlin RL, Miller LS, Bangert C, Stingl G. Innate and adaptive immunity in the skin. Dalam: Wolff K, Goldsmith LA, Katz SI, Gilchrest BA, Paller AS, Leffel DJ, penyunting. Fitzpatrick's dermatology in general medicine. Edisi ke-8. New York: Mc-Graw Hill; 2012. h. 107-8.

8. Gallo RL, Huttner KM. Antimicrobial peptides: An emerging concept in cutaneous biology. J Invest Dermatol. 1998;111:739-43.

9. Vargues T. Antimicrobial peptides - structure, function and resistance. Doctoral dissertation. Edinburgh: University of Edinburgh; 2009. h. 2-20.

10. Andersson ML, Karlsson JMT. CRS-Peptides: Unique defense peptide of mouse Paneth cell. Mucosal Immunol. 2012;5:367-76.

11. Schwarz T. Immunology. Dalam: Bolognia JL, Jorizzo JL, Rapini RP, penyunting. Dermatology. Edisi ke-2. New York: Mosby; 2008. h. 63-77.

12. Zasloff M. Antimicrobial peptides of multicellular organisms. Nature. 2002;425:389-94. efektif terhadap bakteri, jamur, dan virus. ${ }^{26}$ Peptida antimikrobial yang berasal dari hewan dan telah dikembangkan sebagai bentuk obat antara lain Pexiganan $\AA$, yaitu untuk pengobatan topikal ulkus tungkai yang terinfeksi pada pasien diabetes melitus. Peptida antimikrobial (PAM) lain yang sedang diuji dalam fase praklinik adalah Lactoferricin ${ }^{\circledR}$ sebagai antibakteri dan Heliomycin $\AA$ sebagai antijamur. ${ }^{12}$

\section{SIMPULAN}

Peptida antimikrobial bersifat mikrobisidal dan sitolitik, berperan dalam respons imun bawaan sebagai lini pertama dalam pertahanan terhadap infeksi dengan cara membunuh langsung bakteri, jamur, atau virus. Sejumlah PAM telah diidentifikasi berdasarkan kemampuannya dalam menghambat pertumbuhan mikroba patogen.

Penelitian terhadap peranan PAM dalam bidang dermatologi terus dikembangkan. PAM berpotensi tinggi sebagai salah satu obat antimikroba dan efektif terhadap mikroba yang resisten terhadap antibiotik konvensional.

13. Gambichler T, Kobus S, Tigges C, Scola N, Altmeyer P, Kreuter A, dkk. Expression of antimicrobial peptides and proteins in etanercept - treated psoriasis patients. Reg Pept. 2011;167:163-6.

14. Gudjonsson JE, Elder JT. Psoriasis. Dalam: Wolff K, Goldsmith LA, Katz SI, Gilchrest BA, Paller AS, Leffel DJ, penyunting. Fitzpatrick's dermatology in general medicine. Edisi ke-8. New York: Mc-Graw Hill; 2012. h. 197-231.

15. Harder J, Bartels J, Christophers E, Schroder JM. Isolation and characterization of human beta-defensin-3, a novel human inducible peptide antibiotic. J Biol Chem. 2001;276:5707-13.

16. Ong YP, Ohtake T, Brandt C, Strickland I, Boguniewicz M, Ganz T, dkk. Endogenous antimicrobial peptides and skin infections in atopic dermatitis. N Eng J Med. 2002;347:115160.

17. Harder J, Bartels J, Christophers E, Schroder JM. A peptide antibiotic from human skin. Nature. 1997;387:861.

18. Buchau AS, Gallo RL. Innate immunity and antimicrobial defense systems in psoriasis. Clin Dermatol. 2007;25:61624.

19. Peric M, Koglin S, Dombrowski Y, Grob K, Bradac E, Buchau A, dkk. Vitamin D analogs differentially control antimicrobial peptide/"alarmin" expression in psoriasis. PloS ONE. 2009;4(7):755-60.

20. Kim BJ, Rho YK, Lee HI, Jeong MS, Li K, Seo SJ, dkk. The effect of calcipotriol on the expression of human beta defensin-2 an LL-37 in cultured human keratinocytes. Clin Dev Immunol. 2009:645:89-7.

21. Jinquan T, Vorum H, Larsen CG, Madsen P, Rasmussen HH, Gesser B, dkk. Psoriasin-a novel chemotactic protein. J Invest Dermatol. 1996;107:5-10.

22. Rieg S, Steffen H, Seeber S, Humeny A, Kalbacher H, Dietz K, dkk. Deficiency of dermcidin-derived antimicrobial 
peptides in sweat of patients with atopic dermatitis corelates with an impaired innate defense of human skin in vivo. J Immunol. 2005; 174:8003-10.

23. Hofmann SC, Saborowski V, Lange S, Kern WV, Rieg S. Expression of innate defense antimicrobial peptides in hidradenitis supurativa. J Am Acad Dermatol. 2011;66:6.

24. Aoki W, Kuroda K, Ueda M. Next generation of antimicrobial peptides as molecular targeted medicines. J Biosci Bioeng. 2012;114:365-70.
25. Mygind PH, Fischer RL, Schnorr KM, Hansen MT, Raventos $\mathrm{S}$, Buskov S, dkk. Plectasin is a peptide antibiotic with therapeutic potential from a Saprophytic Fungus. Nature. 2005;437:975-80.

26. Zasloff M. Magainins, a class of antimicrobial peptides from Xenopus skin: isolation, characterization of two active forms, and partial cDNA sequence of a precursor. Proc Nat Acad Sci. 1987;84:5449-53. 